\title{
PERLAKUAN AKUNTANSI ASET BIOLOGIS TANAMAN KARET BERDASARKAN INTERNATIONAL ACCOUNTING STANDARD 41 PADA PT. PERKEBUNAN NUSANTARA (PERSERO) XII BANJARSARI
}

\author{
Nurhayati ${ }^{1}$, Yulinartati ${ }^{2}$, Murwanti $^{3}$ \\ ${ }^{123}$ Program Studi Akuntansi Fakultas Ekonomi \\ Universitas Muhammadiyah Jember \\ e-mail: nurhayati1@gmail.com
}

\begin{abstract}
Abstrak
Aset biologis merupakan tanaman dan hewan yang mengalami transformasi biologis Karena mengalami transformasi biologis itu maka diperlukan pengukuran yang dapat menunjukkan nilai dari aset tersebut secara wajar sesuai dengan kontribusinya dalam menghasilkan aliran keuntungan ekonomis bagi perusahaan. Perlakuan akuntansi bagi aset biologis yang diatur dalam International Accounting Standard 41 (IAS 41) yang melingkupi tentang akuntansi bagi sektor usaha agrikultur. IAS 41 mengatur mengenai perlakuan akuntansi, penyajian laporan keuangan, dan pengungkapan. Penelitian ini dilakukan pada PTPN XII Banjarsari yang bergerak dalam bidang perkebunan. Tujuan dari penelitian ini adalah untuk mengetahui bagaimana perlakuan akuntansi aset biologis serta perbandingan perlakuan akuntansi aset biologis yang diterapkan PTPN XII Banjarsari dengan perlakuan akuntansi aset biologis berdasarkan IAS 41. Dalam penelitian ini, penulisan mendasarkan analisis yang dibuat berdasarkan literatur yang relevan dengan topik penelitian serta data yang diperoleh dari tempat penelitian.
\end{abstract}

Kata kunci : Perlakuan Akuntansi, Aset Biologis, IAS 41

\begin{abstract}
Biological assets are plants and animals that undergo biological transformations. Because it undergoes a biological transformation, measurement is needed which can show the value of the asset in a reasonable manner in accordance with its contribution in producing a flow of economic benefits for the company. Accounting treatment for biological assets regulated in International Accounting Standard 41 (IAS 41) which covers accounting for the agricultural business sector. IAS 41 regulates the accounting treatment, presentation of financial statements, and disclosures. This research was conducted at PTPN XII Banjarsari which is engaged in plantation. The purpose of this study was to find out how the accounting treatment of biological assets and the comparison of the accounting treatment of biological assets applied by PTPN XII Banjarsari with the accounting treatment of biological assets based on IAS 41. In this study, writing based analysis made based on literature relevant to the research topic data obtained from the research site.
\end{abstract}

Keywords : Accounting Treatment, Biological Assets, IAS 41 


\section{PENDAHULUAN}

Indonesia merupakan negara agraris yang memiliki keunggulan sebagai produsen komoditas pertanian, data statistik tahun 2016 menunjukkan bahwa sebanyak 32,88\% penduduk di Indonesia bekerja dibidang agrikultur. Perusahaan agrikutur merupakan bagian penting dalam perekonomian Indonesia, hal tersebut terlihat dari data Departemen Pertanian yang menyebutkan bahwa pemanfaatan lahan pertanian di Indonesia setiap tahunnya mengalami peningkatan. Aset yang dimiliki oleh perusahaan agrikultur mempunyai perbedaan dengan perusahaan yang bergerak dibidang lain karena mengalami transformasi biologis serta pengelolaan atas tanaman untuk menghasilkan suatu produk yang dapat dikonsumsi atau diproses lebih lanjut.

Salah satu bentuk informasi dalam bidang ekonomi adalah laporan keuangan yang memberikan informasi tentang posisi keuangan, kinerja keuangan, dan perubahan posisi keuangan serta menjadi informasi tentang keuangan dari sebuah entitas kepada pihak-pihak yang berkepentingan dalam hal untuk pengambilan keputusan bisnis. PT. Perkebunan Nusantara XII adalah salah satu Badan Usaha Milik Negara (BUMN) sektor perkebunan Indonesia. PT. Perkebunan Nusantara XII didirakan berdasarkan Peraturan Pemerintah R.I No.15 Tanggal 14 Februari Tahun 1996 tentang pengalihan bentuk Badan Usaha Milik Negara dari PT Perkebunan (Eks.PTP 19, Eks.PTP 21-22 dan Eks.PTP 27) hasil penggabungan tiga buah PT. Perkebunan (PTP) yang ada di Jawa Timur, yaitu: PT. Perkebunan XXIII, PT. Perkebunan XXVI, dan PT. Perkebunan XXIX menjadi PT. Perkebunan Nusantara XII (Persero) dan tertuang dalam akte Notaris Harun Kamil, SH No. 1 tanggal 2 Desember 2011. IAS 41 mengatur mengenai perlakuan akuntansi, penyajian laporan keuangan, dan pengungkapan terkait dengan kegiatan pertanian yang tidak tercakup dalam standar lainnya. Kegiatan pertanian adalah manajemen oleh entitas transformasi biologis hewan atau tanaman (aset biologis) hidup untuk dijual, menjadi hasil pertanian, atau ke aset biologis tambahan. Selain itu, IAS 41 mengatur, antara lain, perlakuan akuntansi untuk aset biologis selama periode pertumbuhan, degenerasi, produksi, dan prokreasi, serta untuk pengukuran awal hasil pertanian pada titik panen.

Bagaimana perlakuan akuntansi aset biologis PTPN XII Banjarsari terutama dalam hal pengakuan, pengukuran dan pengungkapan. Aset biologis dalam IAS 41 (2009) diartikan sebagai tanaman dan hewan hidup yang dimiliki oleh perusaan atau entitas sebagai akibat peristiwa masa lalu dan mampu memberikan manfaat di masa mendatang. Aset biologis mengalami perubahan seiring dengan berjalannya waktu, perubahan tersebut disebut sebagai transformasi biologis. Transformasi biologis IAS 41 paragraf 5 dapat berupa pertumbuhan (bertambahnya kualitas atau kuantitas (degenerasi), menciptakan tumbuhan baru (prokreasi), dan menghasilkan produk (produksi) (Simanjorang dan Supatmi, 2014).

\section{International Accounting Standard 41 (IAS} 41)

IAS 41 diterbitkan oleh International Accounting Standard Committe (IASC) pada Desember 2000, revisi dilakukan pada tahun 2009. Aset biologis dalam IAS 41 didefinisikan "Biological asset is a living animal or plant". Apabila tanaman atau hewan tersebut dikaitkan dengan aset perusahaan, maka aset biologis merupakan aset yang berupa benda hidup (tanaman ataupun hewan) yang dimiliki perusahaan dengan tujuan untuk mendapatkan keuntungan.

Dibawah ini adalah bagan alur dalam penelitian pada PTPN XII UUS Banjarsari. 


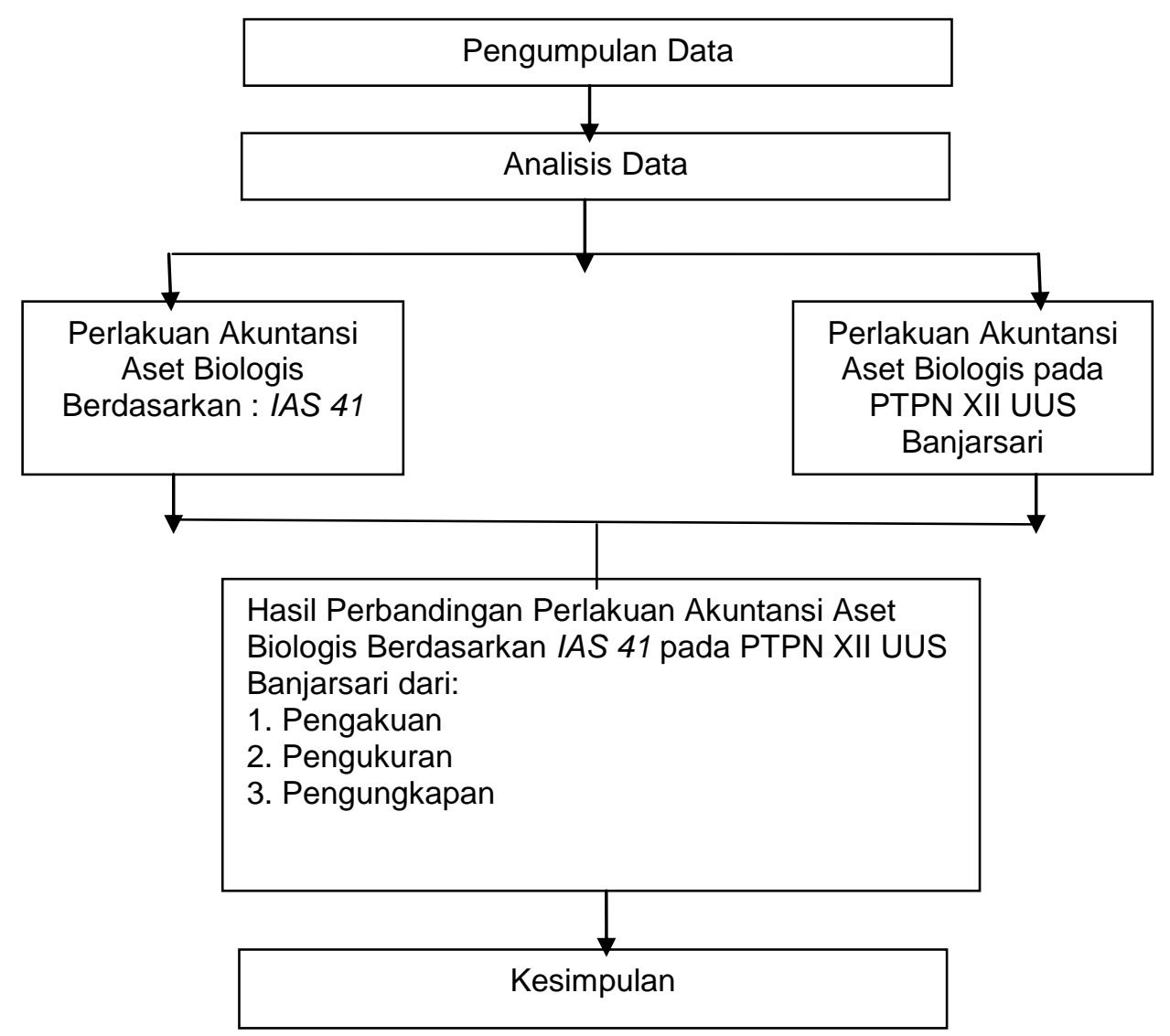

Gambar 1. Bagan Alur dalam penelitian pada PTPN XII UUS Banjarsari

\begin{tabular}{lcr}
\multicolumn{2}{c}{ Kerangka } & pemecah masalah \\
penelitian ini & menjelaskan bahwa \\
pengumpulan data yang dilakukan dengan
\end{tabular} cara studi lapangan, wawancara, dan dokumentasi pada PTPN XII Unit Usaha Stategik (UUS) Banjarsari. Analisis data penelitian ini bersifat dekriptif kualitatif dengan tujuan memberikan gambaran awal mengenai pengukuran, pengakuan dan pengungkapan aset biologis berdasarkan standar yang berlaku di PTPN XII UUS Banjarsari. Setelah mendapatkan gambaran penuh penerapan akuntansi aset biologis pada PTPN XII UUS Banjarsari, langkah berikutnya adalah mengidentifikasi proses pengakuan, pengukuran serta pengungkapan aset biologis berupa tanaman karet pada PTPN XII UUS Banjarsari yang disajikan dalam laporan keuangan. Proses pengakuan, pengukuran, serta pengungkapan aset biologis berupa tanaman karet perkebunan pada PTPN XII UUS Banjarsari yang disajikan dalam laporan keuangan juga dapat dilihat dengan proses pengakuan, pengukuran serta pengungkapan aset biologis berdasarkan standar internasional yaitu IAS 41 yang menyebutkan bahwa aset biologis dalam laporan keuangan harus dinilai dengan nilai wajar pada setiap akhir periode. Selanjutnya membandingkan antara proses pengakuan, pengukuran dan pengungkapan aset biologis berupa tanaman karet perkebunan pada PTPN XII UUS Banjarsari yang disajikan dalam laporan keuangan dengan proses pengakuan, pengukuran dan pengungkapan aset biologis yang mengacu pada Standar Internasional yaitu International Accounting Standard 41 (IAS 41).

\section{METODE}

Jenis data yang digunakan dalam penelitian ini adalah sebagai berikut:

a. Data kualitatif, yaitu data yang berbentuk kata, kalimat, skema dan gambar (Sugiyono, 2004:13). Sumber data dari penelitian ini yaitu data dari perusahaan dalam bentuk informasi baik lisan maupun tulisan seperti sejarah berdirinya perusahaan, struktur organisasi yang disertai uraian tugasnya, serta data-data lain yang bersifat kualitatif yang dibutuhkan dalam rangka penulisan.

b. Data kuantitatif, yaitu data yang berbentuk angka atau data kualitatif yang diangkakan (Sugiyono, 2007:13). Data kuantitatif 
dalam penelitian ini seperti besarnya nilai aset biologis yang diakui oleh perusahaan dalam laporan keuangan, serta data-data lain yang dibutuhkan dalam rangka penulisan.

\section{Metode Analisis}

Penelitian ini bersifat deskriptif kualitatif dengan tujuan untuk memberikan gambaran awal mengenai pengukuran, pengakuan, dan pengungkapan aset biologis berdasarkan standar yang berlaku di PTPN XII Banjarsari. Untuk menjawab rumusan masalah, maka metode analisis yang digunakan adalah metode analisis deskriptif kualitatif. Dengan metode analisis deskriptif kualitatif, data yang diperoleh diidentifikasi secara kualitatif, yaitu dengan mengkaji, memaparkan, menelaah, dan menjelaskan data-data yang diperoleh pada PTPN XII Unit Usaha Strategik Banjarsari untuk mendapatkan gambaran yang jelas dan menyeluruh tentang proses pengakuan, pengukuran, serta pengungkapan aset biologis berupa tanaman perkebunan pada PTPN XII Banjarsari hingga tersaji dalam laporan keuangan.

\section{HASIL DAN PEMBAHASAN}

Perbandingan Pengakuan Aset Biologis PTPN XII Banjarsari dengan IAS 41

Tabel 1. Perbandingan Pengakuan Aset Biologis PTPN XII Banjarsari dengan IAS 41

\begin{tabular}{|c|c|}
\hline PTPN XII Banjarsari & IAS 41 \\
\hline $\begin{array}{l}\text { Aset biologis terbagi atas Tanaman } \\
\text { Menghasilkan, Tanaman Belum Menghasilkan, } \\
\text { Persediaan hasil panen. } \\
\quad \text { Tanaman Menghasilkan dan Tanaman } \\
\text { Belum Menghasilkan diklasifikasikan menjadi } \\
\text { aset tidak lancar dan persediaan } \\
\text { diklasifikasikan menjadi aset lancar. }\end{array}$ & $\begin{array}{l}\text { Aset biologis diakui sebagai Aset biologis } \\
\text { dewasa, Aset biologis belum dewasa, dan } \\
\text { persediaan. } \\
\text { Aset biologis dewasa diklasifikasikan aset } \\
\text { tidak lancar, aset biologis belum dewasa } \\
\text { diklasifikasikan aset lancar dan persediaan } \\
\text { diklasifikasikan menjadi aset lancar. }\end{array}$ \\
\hline $\begin{array}{l}\text { Penyusutan dihitung berdasarkan taksiran } \\
\text { masa manfaat ekonomis aset tanaman dengan } \\
\text { menggunakan metode garis lurus. }\end{array}$ & $\begin{array}{l}\text { Penyusutan diakui ketika nilai wajar tidak } \\
\text { dapat ditemukan sehingga perusahaan menilai } \\
\text { aset biologis dengan biaya perolehan, dan } \\
\text { metode serta tarif penyusutan sesuai dengan } \\
\text { kebijakan perusahaan. }\end{array}$ \\
\hline
\end{tabular}

Berdasarkan Tabel diatas, pengakuan atas tanaman karet menurut PTPN XII Banjarsari dan IAS 41 secara umum sama, perbedaannya hanya terletak pada istilah aset biologis, namun keduanya sama-sama mengklasifikasikan aset tersebut mengikuti transformasi atau pertumbuhan aset. Aset biologis belum dewasa menurut IAS 41 sama halnya Tanaman Belum Menghasilkan (TBM) di PTPN XII Banjarsari, sementara aset biologis dewasa merupakan Tanaman Menghasilkan (TM) di PTPN XII Banjarsari, dimana aset biologis belum dewasa yang sudah memenuhi syarat diakui sebagai aset biologis dewasa direklasifikasi menjadi aset biologis dewasa. Selanjutnya produk agrikultur pada titik panen diakui sebagai persediaan, dimana PTPN XII Banjarsari mengakui persediaan dari titik panen sampai menjadi barang jadi, sedangkan IAS 41 hanya mengatur standar aset biologis sampai persediaan pada titik panen saja. IAS 41 diterapkan pada produk agrikultur berupa hasil pertanian pada titik panen namun untuk pengolahan produk agrikultur menjadi persediaan barang jadi tidak diatur di dalam IAS 41 tetapi diatur sendiri di dalam IAS 2 tentang inventory (IAS 41 paragraf 3) atau jika di Indonesia menggunakan PSAK 14 tentang persediaan.

Jika pengukuran aset biologis menurut PTPN XII Banjarsari di atas dibandingkan dengan IAS 41, maka dapat dilihat dalam berikut ini:

Perbandingan Pengukuran Aset Biologis PTPN XII Banjarsari dengan IAS 41 
Tabel 2. Perbandingan Pengukuran Aset Biologis PTPN XII Banjarsari dengan IAS 41

\begin{tabular}{l|ll}
\hline \multicolumn{1}{c|}{ PTPN XII Banjarsari } & IAS 41 \\
\hline $\begin{array}{l}\text { Aset biologis berupa TM dan TBM diukur } \\
\text { sebesar harga perolehan dikurangi akumulasi }\end{array}$ & $\begin{array}{c}\text { Aset biologis berupa aset biologis dewasa } \\
\text { dan aset biologis belum dewasa diukur sebesar } \\
\text { penyusutan sedangkan aset biologis berupa } \\
\text { persediaan diukur sebesar nilai yang lebih } \\
\text { nendah antara harga perolehan dan realisasi } \\
\text { menjual }\end{array}$ \\
$\begin{array}{l}\text { bersih } \\
\text { Mengukur atau menghitung penyusutan ketika } \\
\text { aset biologis telah dikategorikan sebagai TM }\end{array}$ & Tidak mengukur atau menghiting \\
\hline
\end{tabular}

Berbeda dengan pengukuran aset biologis menurut PTPN XII Banjarsari, aset biologis menurut lingkup IAS 41 harus diukur pada pengakuan awal dan pada tanggal pelaporan berikutnya pada nilai wajar berbasis harga pasar aktif setelah dikurangi dengan taksiran biaya untuk menjual, kecuali nilai wajar tidak dapat diukur secara andal. Harga pasar aktif menurut IAS 41 sulit diketahui. Ketika nilai wajar tidak dapat ditentukan maka perusahaan dianjurkan menggunakan biaya perolehan dikurangi akumulasi penyusutan dan akumulasi penurunan nilai, tetapi apabila di kemudian hari nilai wajar dapat ditentukan maka tanaman perkebunan yang telah dinilai menggunakan biaya perolehan dikurangi akumulasi penyusutan dan akumulasi penurunan nilai tersebut harus dinilai kembali menggunakan nilai wajar dikurangi taksiran biaya untuk menjual (IAS 41 paragraf 30).

Perbandingan Pengungkapan Aset Biologis PTPN XII Banjarsari dengan IAS 41

Tabel 3. Perbandingan Pengungkapan Aset Biologis PTPN XII Banjarsari dengan IAS 41

\begin{tabular}{|c|c|}
\hline jarsari & IAS 41 \\
\hline $\begin{array}{l}\text { Mengungkapkan jenis dan jumlah aset } \\
\text { biologis } \\
\text { Tidak hanya mengungkapkan aset } \\
\text { biologis pada aktivitas agrikultur saja tetapi } \\
\text { juga mengungkapkan pengelolaan produk } \\
\text { agrikultur pada titik panen menjadi produk jadi }\end{array}$ & $\begin{array}{l}\text { Mengungkapkan jenis dan jumlah aset } \\
\text { biologis } \\
\text { Hanya mengatur perlakuan akuntansi dan } \\
\text { hanya mengungkapkan aset biologis yang } \\
\text { berhubungan dengan kegiatan pertanian. Untuk } \\
\text { pengolahan hasil panen menjadi produk jadi tidak } \\
\text { diungkapkan }\end{array}$ \\
\hline $\begin{array}{l}\text { Mengungkapkan dasar pengkuran yang } \\
\text { digunakan dalam menentukan jumlah tercatat } \\
\text { aset biologis } \\
\text { Mengungkapkan adanya depresiasi ang } \\
\text { berdampak pada laba-rugi pada tahun } \\
\text { berjalan, serta mengungkapkan metode } \\
\text { penyusutan yang digunakan, umur, manfaat } \\
\text { ekonomi, dan tarif penyusutan }\end{array}$ & $\begin{array}{l}\text { Mengungkapkan kebijakan akuntansi yang } \\
\text { digunakan dalam pengukuran aset biologis } \\
\text { Tidak mengungkapkan adanya penyusutan } \\
\text { aset biologis, maka pada laporan laba/rugi tidak } \\
\text { ada beban depresiasi yang berakibat adanya } \\
\text { kenaikan pada laporan laba/rugi }\end{array}$ \\
\hline
\end{tabular}

Penyajian dan pengungkapan aset biologis menurut PTPN XII Banjarsaridengan IAS 41 mempunyai kesamaan dalam hal pengungkapan jumlah dan jenis aset serta sama-sama mengungkapkan dasar pengukuran yang digunakan dalam menentukan jumlah tercatat aset biologis. Sedangkan perbedaannya yaitu IAS 41 hanya mengatur dan mengungkapkan aset biologis sampai pada titik panen saja, sedangkan PTPN XII Banjarsari mengungkapkan aset biologis berupa pengolahan produk agrikultur pada titik panen menjadi produk jadi. Selain itu, IAS 41 tidak mengungkapkan adanya penyusutan aset biologis, maka pada laporan laba/rugi tidak ada beban depresiasi yang berakibat adanya kenaikan pada laporan laba/rugi sedangkan PTPN XII Banjarsari mengungkapkan adanya depresiasi yang berdampak pada penurunan laba - rugi pada tahun berjalan sehingga PTPN XII Banjarsari mengungkapkan metode penyusutan yang digunakan, umur, manfaat ekonomi, dan tarif penyusutan yang digunakan.

\section{PENUTUP}

Berdasarkan penelitian yang telah dilakukan pada PTPN XII Banjarsari, diperoleh kesimpulan sebagai berikut:

PTPN XII Banjarsari dalam melakukan perlakuan akuntansi aset biologisnya telah 
menggunakan standar akuntansi yang berlaku di Indonesia yaitu prinsip akuntansi yang didasarkan pada Standar Akuntansi Keuangan (SAK) yang mencakup PSAK 14 tentang persediaan dan PSAK 16 tentang aset tetap serta peraturan pemerintah yang lain yang berlaku dalam penyajian laporan keuangan perusahaan. Terkait pengakuan terdapat perbedaan dalam hal istilah atau nama akun untuk aset biologis, namun secara konsep tidak berbeda karena sama-sama mengikuti transformasi aset biologis. Dalam pengukuran pada PTPN XII Banjarsari aset biologis berupa TM dan TBM diukur sebesar harga perolehan dikurangi akumulasi penyusutan. Untuk pengungkapan pada PTPN XII Banjarsari mengungkapkan jenis dan jumlah aset biologis pada aktivitas agrikultur dan mengungkapkan pengelolaan produk agrikultur pada titik panen menjadi produk jadi.

Perbedaan perlakukan akuntansi aset biologis antara PTPN XII Banjarsari dengan IAS 41 lebih kepada aspek pengukurannya, dimana PTPN XII Banjarsari lebih didasarkan pada harga perolehan sehingga mengenal adanya penyusutan, sedangkan IAS 41 diukur sebesar nilai wajar dikurangi taksiran biaya untuk menjual. Artinya ada yang membuat perbedaan dalam penyajian dan pengungkapan di dalam laporan keuangan. Perlakuan akuntansi aset biologis PTPN XII Banjarsari telah didasarkan pada PSAK 14 tentang persediaan dan PSAK 16 tentang aset tetap. Untuk itu, IAS 41 kurang cocok diterapkan karena di Indonesia nilai wajar masih sulit ditentukan. Dalam pengungkapan aset biologis pada PTPN XII Banjarsari dengan IAS 41 memiliki perbedaan yaitu IAS 41 hanya mengatur dan mengungkapkan aset biologis sampai pada titik panen, sedangkan PTPN XII Banjarsari mengungkapkan aset biologis berupa pengolahan produk agrikultur pada titik panen menjadi produk jadi. Selain itu, IAS 41 tidak mengungkapkan adanya penyusutan aset biologis, maka pada laporan laba/rugi tidak ada beban depresiasi yang berakibat adanya kenaikan pada laporan laba/rugi sedangkan PTPN XII Banjarsari mengungkapkan adanya depresiasi yang berdampak pada penurunan laba/rugi tahun berjalan sehingga PTPN XII Banjarsari mengungkapkan metode penyusutan yang digunakan, umur, manfaat ekonomi, dan tarif penyusutan.

\section{DAFTAR PUSTAKA}

Adita dan Kiswara. 2012. Analisis Penerapan International Accounting Standard (IAS) 41. Diponegoro.

Aisyah, Siti. 2017. Analisis Perlakuan Aset Biologis Berdasarkan PSAK NO 69 Tentang Agrikultur pada PTPN $X$ Jember Kebun Kertosari. Fakultas Ekonomi Universitas Muhammadyah Jember.

Damba Satria, Dandy. 2008. Perlakuan Akuntansi Atas Aktiva Biologis dan Penyajiannya dalam Laporan Keuangan Perusahaan. Surabaya: Universitas Airlangga

Dame Simaanjorang, Rani. 2014. Praktek Perlakuan Akuntansi Aset Biologis pada Perusahaan Perkebunan (Persero) di Indonesia. Fakultas Ekonomika dan Bisnis, Universitas Kristen Setya Wacana.

Dewan Standar Akuntansi Keuangan Ikatan Akuntansi Indonesia (DSAKIAl). 2015. Exposure Draft Pernyataan Standar Akuntansi Keuangan No. 69, Agriculture

E. Keiso, Jerry J, Weygandt and Teery D. Warfield, 2007. Accounting Principles, Edisi 12 by: Salemba Empat.

Farida, Ike. 2011. Anakisis Perlakuan Akuntansi Aset Biologis Berdasarkan International Accounting Standard 41 pada PTPN VII (Persero). Fakultas Ekonomi Universitas Negeri Surabaya.

Goncaleves, Rute and Patricia,Lopes. 2013. Firm-apecific Determinants of Agricultural Financial Reporting

Harahap, S.S. 2007. Akuntansi Keuangan Menengah. Yogyakarta: BPFE.

International Accounting Standard Committee (IASC). 2000. International Accounting Standard No. 41, Agriculture.

Ikatan Akuntan Indonesia. 2015. ED PSAK 69 Agrikultur. Dewan Standar Akuntansi Keuangan.

Munawir, S, 2002. Analisis Laporan Keuangan, Edisi Kedua, YPKN, Yogyakarta.

Pratiwi, Wike. 2017. Analisis Perlakuan Akuntansi Aset Biologis Berbasis PSAK 69 Agrikultur pada PTPN XII Kalisanen 
Kabupaten Jember. Universitas Negeri Jember.

Ridwan ABD, Achmad. 2011. Perlakuan Akuntansi Aset Biologis PTPN. XIV Makasar (Persero). Fakultas Ekonomi Universitas Hasanudin Makasar.

Yuwanita Sari, Ana. 2015. Analisis Pengakuan, Pengukuran, Pengungkapan dan Penyajian Aset Biologis Berdasarkan Standar Akuntansi Keuangan pada PTPN IX (Persero). Fakultas Ekonomi dan Bisnis Universitas Muhammadyah Surakarta. 